\title{
Hesperidin Extracted from Citrus reticulata Blanco Protects Cardiac Mitochondria Against Hypoxia/Reoxygenation Injury
}

\author{
Vu Thi Thu ${ }^{1, *}$, Phuong Thien Thuong ${ }^{2}$ \\ ${ }^{I}$ VNU University of Science, 334 Nguyen Trai, Thanh Xuan, Hanoi, Vietnam \\ ${ }^{2}$ Vietnam-Korea Institute of Science and Technology, Hoa Lac High-tech Park, Thach That, Hanoi, Vietnam
}

Received 19 September 2021

Revised 28 Octorber 2021; Accepted 01 November 2021

\begin{abstract}
This study was conducted to evaluate the protective effect of Hesperdin (Hes) extracted from Citrus reticulata Blanco on cardiac mitochondria in hypoxia/reoxygenation (HR) injury in vitro. $\mathrm{H} 9 \mathrm{C} 2$ cardiomyocytes were cultured under normal (control), HR, and treatment conditions. The reactive oxygen species and calcium levels in experimental groups were analyzed by using suitable fluorescence kits. The obtained results showed that the addition of Hes at dose of $0.01562 \mathrm{mg} / \mathrm{mL}$ sharply decreased the mitochondrial oxidative stress of $\mathrm{H} 9 \mathrm{C} 2$ cells under HR conditions. In particular, Hes showed the remarkable efficiency in maintaing cellular calcium levels. In HR-exposed $\mathrm{H} 9 \mathrm{C} 2$ cell group, the hydrogen peroxide and superoxide levels were highly increased compared to those in control group $(1.54 \pm 0.06$ and $1.74 \pm 0.38, \mathrm{p}<0.05)$. HR also strongly induced the elevation of cytosolic $\mathrm{Ca}^{2+}$ and mitochondial $\mathrm{Ca}^{2+}$ of $\mathrm{H} 9 \mathrm{C} 2$ cardiomyocytes with the values were $1.96 \pm 0.05 \%$ and $1.62 \pm 0.33$ (ratio to control, $\mathrm{p}<0.05$ ), respectively. Interestingly, post-hypoxic supplementation of Hes effectively abolished the negative increment of these indicators with the lower levels of hydrogen peroxide and superoxide levels $(1.00 \pm 0.10$ and $1.29 \pm 0.03, \mathrm{p}<0.05)$ and the better modulation of cytosolic and mitochondrial $\mathrm{Ca}^{2}$ homeostasis $(1.94 \pm 0.05$ and $1.25 \pm 0.01)$ compared to those in HR-treated cells. The present results are pilot data on the effects of Hes in protecting cardiac mitochondria against HR injury.
\end{abstract}

Keywords: Hesperidin, Mitochondria, Hypoxia/reoxygenation, Calcium.

\section{Introduction}

Heart attack or ischemic heart disease is characterized by reduced blood supply to the heart tissue $[1,2]$. Ischemic heart disease is normally unpredictable and rescuing the patient

\footnotetext{
* Corresponding author.

E-mail address: vtthu2015@gmail.com

https://doi.org/10.25073/2588-1140/vnunst.5328
}

depends on revascularization time and on the drugs administered during reperfusion. Effective intervention for rescuing the patient depends on myocardial ischemia duration and revascularization time [3]. However, reperfusion with restoration of normal oxygen level to ischemic myocardium can also result in severe or irreversible injury to heart, so called ischemia/reperfusion (IR) or hypoxia/reoxygenation (HR) injury [4-7]. At 
the celllular levels, phenomena of the malfunctions include an excessive generation of reactive oxygen species (ROS) [8], an overload of mitochondrial calcium, and cell death $[4,9]$. As mitochondria play important role in physiological and pathological processes, many reports have focused on the assessment of anti-ischemic drugs based on mitochondrial functional analysis $[10,11]$.

In recent decades, there has been great progress in screening and identifying natural compounds to develop new drugs, which can be used to preserve mitochondrial function and subsequently to improve cardiac function. Though Vietnamese plant compounds have been demonstrated to have the ability to reduce oxidative stress, inflammation and apoptosis [12-15], the functions of these promised candidates on treatment of ischemic heart disease are not fully understood yet.

Of those, Hesperidin (Hes) is a flavanone glycoside with a wide range of biological effects found primarily in the peels of citrus fruits (genus Citrus) [16-18]. Previous research demonstrated that Hes possesses the lipid peroxidation and antioxidant activities [18]. Hes reduces oxidative stress, apoptosis and improves cardiac function via the peroxisome proliferator-activated receptor gamma (PPAR $\gamma)$ pathway in isoproterenol-induced myocardial dysfunction in rat diabetes [17]. The preventive effect of Hes modulated the inflammatory response and antioxidant status following acute myocardial infarction through downregulation of the expression of PPAR $\gamma$ and B-cell lymphoma $2(\mathrm{Bcl} 2)$ in the model animal. Moreover, pretreatment with Hes protects against myocardial IR injury by suppressing myocardial apoptosis, the inflammatory response and oxidative stress [19]. A recent study had demonstrated that Hes could be a potential active compound in protecting H9C2 against HR injury targeting mitochondria [20]. Post-hypoxic treatment of Hes reduced H9C2 cardiomyocyte death and preserved mitochondrial cardiolipin content [20]. However, the mechanism underlying the protective effects of Hes against malfunction of cardiac mitochondria remains poorly defined. Therefore, in this study, we isolated Hes from Citrus reticulata Blanco and then evaluated the protective effects of Hes on $\mathrm{H} 9 \mathrm{C} 2$ cells by examining ROS and calcium levels.

\section{Materials and Methods}

\subsection{Materials}

The main materials and equipments used in this study were fruit peels of Citrus reticulata Blanco (Hanoi, Vietnam), H9C2 cell line (ATCC $^{\circledR}$-USA), Dulbecco's Modified Eagle Medium 4.5g/L glucose (DMEM, Gibco, USA), Fetal bovine serum (FBS, Gibco, USA), Penicillin-Streptomycin (PS, Gibco, USA), Phosphate buffered saline (PBS, Gibco, USA), Dimethyl Sulfoxide (DMSO, Sigma, USA), phosphate buffer saline, $\mathrm{MeOH}$, 2',7'-dichlorodihydrofluorescein-diacetate $\left(\mathrm{CM}-\mathrm{H}_{2}\right.$ DCFDA; ex/em 485/525 nm, Invitrogen, USA); MitoSOX Red (ex/em: 510/580 nm, Invitrogen, USA); Rhod-2 AM ( $5 \mu \mathrm{M}$, ex/em: $533 / 576 \mathrm{~nm}$, Invitrogen, USA), Fluo-4 AM $(5 \mu \mathrm{M}$, ex/em: 488/525 nm, Invitrogen, USA), $\mathrm{MeOH}$, Culture dishes 90x20 mm (SPL, Korea), 96-well black, glass bottom plates (CAT. 33196, SPL), $\mathrm{CO}_{2}$ Incubator (Shellab, USA); and Microplate reader (Tristar, USA), liquid chromatography-mass spectrometry (LCMS-8045, Shimadzu, Japan).

\subsection{Methods}

\subsubsection{Hesperidin Preparation \\ Sample preparation}

The peels of citrus fruits (Citrus reticulata Blanco) were sliced (3-4 cm long and $0.5-1 \mathrm{~cm}$ wide) and then dried in an oven at $60{ }^{\circ} \mathrm{C}$ until the moisture content less than $10 \%$.

\section{Extraction and purification of hesperidin}

The dried sample $(1 \mathrm{~kg})$ was powdered and extracted with methanol $(\mathrm{MeOH})$ under reflux three times (each $10 \mathrm{~L}$ ). After filtration, the combined $\mathrm{MeOH}$ extract was evaporated to about one-half its original volume, and then partitioned with $n$-hexane to remove impurities. The remaining $\mathrm{MeOH}$ extract was concentrated 
to remove the solvent, then cooled below $10{ }^{\circ} \mathrm{C}$; then a crude precipitate $(\mathrm{CF}-2,11.6 \mathrm{~g})$ was obtained.

The crude CF-2 (4.7 g) was refluxed with $\mathrm{MeOH}(1 \mathrm{~L})$ for $60 \mathrm{~min}$. The solution was then filtered and allowed to stand at $5{ }^{\circ} \mathrm{C}$ for $48 \mathrm{~h}$ in order to crystallize. The crystals of CF- 2 were filtered off and dried at $60{ }^{\circ} \mathrm{C}$ for $2 \mathrm{~h}$. After that, the white crystalline CF-2 (3.75 g) was collected. The yield of purification was $79.8 \%$.

2.2.2. Cell Culture and HypoxiaReoxygenation In Vitro Model

H9C2 cells were maintained in normal condition (DMEM, 10\% FBS, and 1\% PS at $37{ }^{\circ} \mathrm{C}$ with $5 \% \mathrm{CO}_{2}$ ) and subjected to $\mathrm{HR}$ model and treatment as previously described [20]. For HR in vitro model, H9C2 cells were further transferred to 96-well black, glass bottom plates at density of $5.10^{3}$ cells/well at $37{ }^{\circ} \mathrm{C}, 5 \% \mathrm{CO}_{2}$. After $24 \mathrm{~h}$, the cells were then subjected to hypoxic condition and treatments. The experimental cells were divided into different groups. For control group, H9C2 cells were continously cultured under normal condition for 48 h. For HR groups, H9C2 cells were cultured in serum-free low-glucose DMEM at $37{ }^{\circ} \mathrm{C}, 95 \% \mathrm{~N}_{2}, 5 \% \mathrm{CO}_{2}$, and $2 \%$ $\mathrm{O}_{2}$ for $6 \mathrm{~h}$. Then, the old medium was removed. The $\mathrm{H} 9 \mathrm{C} 2$ cells were then transferred to normal condition for reoxygenation for $24 \mathrm{~h}$. The HR groups were further devided to sub-groups based on post-hypoxic treatments:

i) HR group: the reoxygenation stage normal culture condition;

ii) $\mathrm{RuR}$ group: the reoxygenation stage medium contained DMEM, $10 \%$ FBS, $1 \%$ PS, and Ruthenium Red (RuR) at doses of $5 \mu \mathrm{M}$. $\mathrm{RuR}$ was used as positive control of mitochondrial calcium uniporter (MCU) inhibitor.

iii) Hes group: the reoxygenation stage medium contained DMEM, 10\% FBS, 1\% PS, and Hes at doses of $0.01562 \mathrm{mg} / \mathrm{mL}$ as previous study [20].

RuR and Hes stocks were prepared in DMSO and the final concentration of DMSO in cultured medium was about $0.1 \%$. At the end of the experiment period, ROS and $\mathrm{Ca}^{2+}$ levels were tested by the suitable fluorescence kits.
2.2.3. Measurement of Reactive Oxygen Species and $\mathrm{Ca}^{2+}$ Levels

Mitochondrial hydrogen peroxide $\left(\mathrm{H}_{2} \mathrm{O}\right)$ and superoxide $\left(\mathrm{O}_{2}{ }^{-}\right)$, mitochondrial $\mathrm{Ca}^{2+}$ and cytosolic $\mathrm{Ca}^{2+}$ levels were indirectly assessed as following a previously described [4, 21]. H9C2 cells were seeded in 96-well black, glass bottom plates and subjected to HR model and treatments. After being subjected to different conditions, cells were double stained with CM- $\mathrm{H}_{2}$ DCFDA $(5 \mu \mathrm{M})$ and MitoSOX Red $(5 \mu \mathrm{M})$; or with Rhod-2 AM $(5 \mu \mathrm{M})$ and Fluo-4 AM $(5 \mu \mathrm{M})$ to detect changes in mitochondrial $\mathrm{H}_{2} \mathrm{O}_{2}, \mathrm{O}_{2}{ }^{-}$levels; or $\mathrm{Ca}^{2+}$ and cytosolic $\mathrm{Ca}^{2+}$ levels, respectively. After washing twice with phosphate buffer saline, samples were analyzed using a microplate reader. The total fluorescence intensities were expressed as ratio relatives to normal control. Experiments were performed 3-6 times.

\subsubsection{Statistical Analysis}

Origin 8.0 software was chosen to analyze data. Data are presented as means \pm Standard error of the mean (SEM). Differences between the two groups were evaluated by ANOVA and Turkey test. A p-value $\leq 0.05$ was considered to be significant.

\section{Results and Discussion}

\subsection{Hesperidin (CF-2) Extracted From Citrus Reticulata Blanco}

The obtained compound CF-2 were characterized with white crystalline; $\mathrm{mp}$. 252-254 ${ }^{\circ} \mathrm{C}$; UV (MeOH) $\lambda_{\max }: 284.326 \mathrm{~nm}$; IR $(\mathrm{KBr}) v_{\max } \mathrm{cm}^{-1}: 3439$ (phenolic $\mathrm{OH}$ ), 2983, $2934(\mathrm{C}-\mathrm{H}), 1648(\mathrm{C}=\mathrm{O}), 1607,1520,1447$ (aromatic $\mathrm{C}=\mathrm{C}), 1280,1205,1132,1072(\mathrm{C}-\mathrm{O})$; ESI-MS: $\quad m / z \quad 609.4 \quad[\mathrm{M}-\mathrm{H}]^{-} \quad\left(\mathrm{C}_{28} \mathrm{H}_{33} \mathrm{O}_{15}\right)$; ${ }^{1} \mathrm{H}-\mathrm{NMR}\left(500 \mathrm{MHz}, \mathrm{DMSO}-d_{6}\right) \delta_{\mathrm{H}}: 5.50(1 \mathrm{H}, \mathrm{dd}$, $J=3.0,12.5 \mathrm{~Hz}, \mathrm{H}-2), 2.77(1 \mathrm{H}, \mathrm{dd}, J=3.0$, $17.5 \mathrm{~Hz}, \mathrm{H}-3), 3.27(1 \mathrm{H}, \mathrm{dd}, J=12.5,17.5 \mathrm{~Hz}$, $\mathrm{H}-3), 6.14(1 \mathrm{H}, \mathrm{d}, J=2.0 \mathrm{~Hz}, \mathrm{H}-6), 6.12(1 \mathrm{H}, \mathrm{d}$, $J=2.0 \mathrm{~Hz}, \mathrm{H}-8), 6.94\left(3 \mathrm{H}, \mathrm{m}, \mathrm{H}-2^{\prime}, \mathrm{H}-5^{\prime}, \mathrm{H}-6^{\prime}\right)$, $9.08\left(1 \mathrm{H}, \mathrm{s}, 3^{\prime}-\mathrm{OH}\right), 12.01(1 \mathrm{H}, \mathrm{s}, 5-\mathrm{OH})$, Glc: 
$4.97\left(1 \mathrm{H}, \mathrm{d}, J=7.5 \mathrm{~Hz}, \mathrm{H}-1^{\prime \prime}\right)$, Rha: 4.52 $\left(1 \mathrm{H}, \mathrm{s}, \mathrm{H}-1^{\prime \prime \prime}\right), 1.08\left(3 \mathrm{H}, \mathrm{d}, J=6.0 \mathrm{~Hz}, \mathrm{H}-6^{\prime \prime \prime}\right)$; ${ }^{13} \mathrm{C}-\mathrm{NMR}\left(125 \mathrm{MHz}, \mathrm{DMSO}-d_{6}\right) \delta_{\mathrm{C}}: 78.4(\mathrm{C}-2)$, 42.0 (C-3), 197.0 (C-4), 163.0 (C-5), 96.4 (C-6), 165.1 (C-7), 95.5 (C-8), 162.5 (C-9), 103.3 (C-10), $130.9\left(\mathrm{C}-1^{\prime}\right), 114.1\left(\mathrm{C}-2^{\prime}\right), 146.6\left(\mathrm{C}-3^{\prime}\right), 148.0$ (C-4'), $112.0\left(\mathrm{C}-5^{\prime}\right), 117.9\left(\mathrm{C}-6^{\prime}\right), 55.7\left(\mathrm{OCH}_{3}\right)$, Glc: 100.6 (C-1"), 73.0 (C-2"), 76.3 (C-3"), 69.6

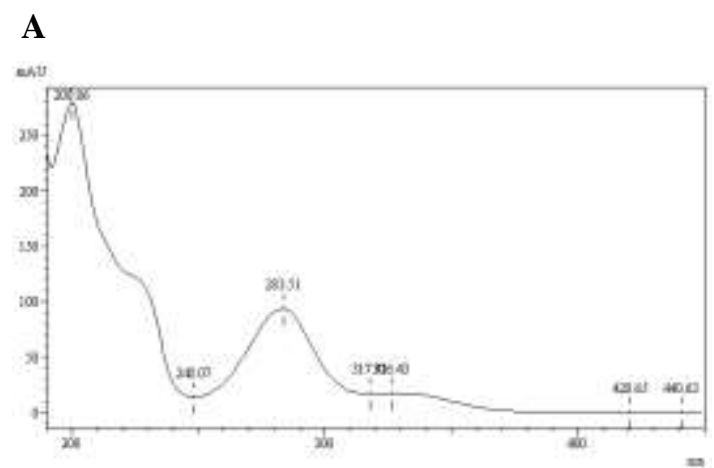

C

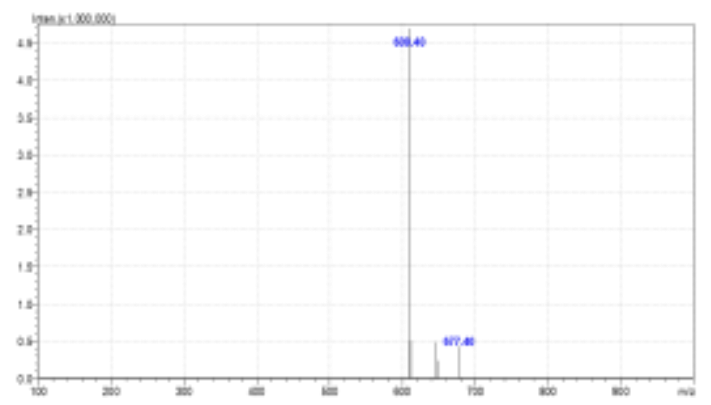

(C-4"), 75.5 (C-5"), 66.0 (C-6"), Rha: 99.5 (C-1"'), $70.3 \quad\left(\mathrm{C}-2^{\prime \prime \prime}\right), \quad 70.7 \quad\left(\mathrm{C}-3^{\prime \prime \prime}\right), \quad 72.1 \quad\left(\mathrm{C}-4^{\prime \prime \prime}\right)$, $68.3\left(\mathrm{C}-5^{\prime \prime \prime}\right), 17.8\left(\mathrm{C}-6^{\prime \prime \prime}\right)$.

The spectral data of CF-2 was completely identical with those of published Hesperidin [22]. In this study, the natural purified CF-2 compound was determined to be hesperidin as shown in Figure 1.

\section{B}

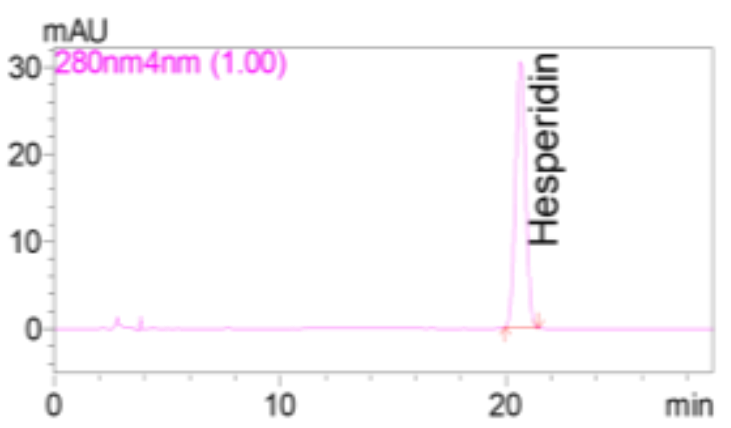

D

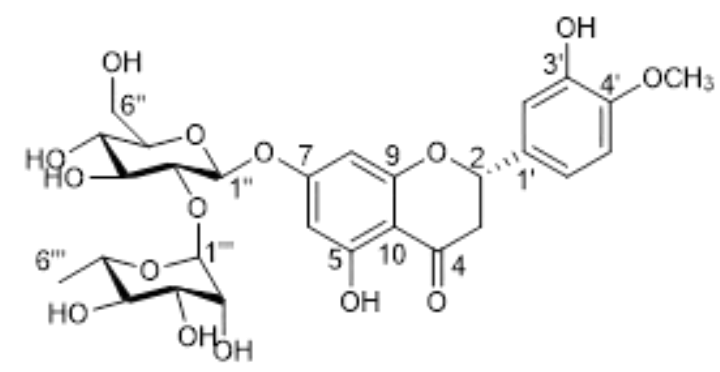

Figure 1. Hesperidin (CF-2) extracted from Citrus Reticulata Blanco.

A: The absorption spectrum; B: HPLC chromatogram; C: Mass spectrum; D: The structure of Hesperidin.

\subsection{Hesperidin Decreased Oxidative Stress in HR Injury}

H9C2 cells were cultured in normal condition or sujected to HR conditions. With RuR and Hes groups, the HR-subjected cells were supplied with RuR and Hes at the selected dose to culture media during reoxygenation period. The effects on the levels of reactive oxygen species in $\mathrm{H} 9 \mathrm{C} 2$ cells were shown in Figure 2.

Previous researches had demonstrated that Hes exerts cardioprotective and anti-diabetic properties in in vivo rat model by reducing oxidative stress and apoptosis and improving cardiac function $[17,19]$. The study showed that treatment of Hes decreased the down-regulated $\operatorname{PPAR} \gamma$ and $\mathrm{Bcl} 2$ apoptosis regulator expressions in myocardial infarcted diabetic hearts [17]. Short-term pretreatment with Hes protected against myocardial IR injury by suppressing myocardial apoptosis, the inflammatory response and oxidative stress via phosphoinositide 3-kinases/protein kinase B pathway activation and high mobility group box 1 protein inhibition [19]. Recently study had demonstrated that Hes also protected $\mathrm{H} 9 \mathrm{C} 2$ cells against HR damage by decreasing cell death and preserving mitochondrial cardiolipin content [20]. Consistent with these researches, 
our data demonstrated that $\mathrm{HR}$ significantly increased the $\mathrm{H}_{2} \mathrm{O}_{2}$ and $\mathrm{O}_{2}{ }^{-}$levels in $\mathrm{H} 9 \mathrm{C} 2$ cells to $1.54 \pm 0.06$ and $1.74 \pm 0.38$ (ratio to control, $\mathrm{p}<0.05)$. Post-hypoxic treatment of RuR and Hes effectively decreased $\mathrm{H}_{2} \mathrm{O}_{2}$ and $\mathrm{O}_{2}{ }^{-}$overproduction with the ratio values (to control) were about $1.00 \pm 0.10$ and $1.29 \pm 0.03$, respectively (Figure 2). Particularly, $\mathrm{H}_{2} \mathrm{O}_{2}$ levels in Hes-treated cells was significant lower than in RuR-treated cells (Figure 2A, $\mathrm{p}<0.05$ ), suggesting the ability of Hes in limiting oxidative stress under HR injury was stronger than RuR. Also, the insignificant $\mathrm{O}_{2}{ }^{-}$levels between RuR and Hes could be a result of the rapid conversion of $\mathrm{O}_{2}{ }^{-}$to $\mathrm{H}_{2} \mathrm{O}_{2}$

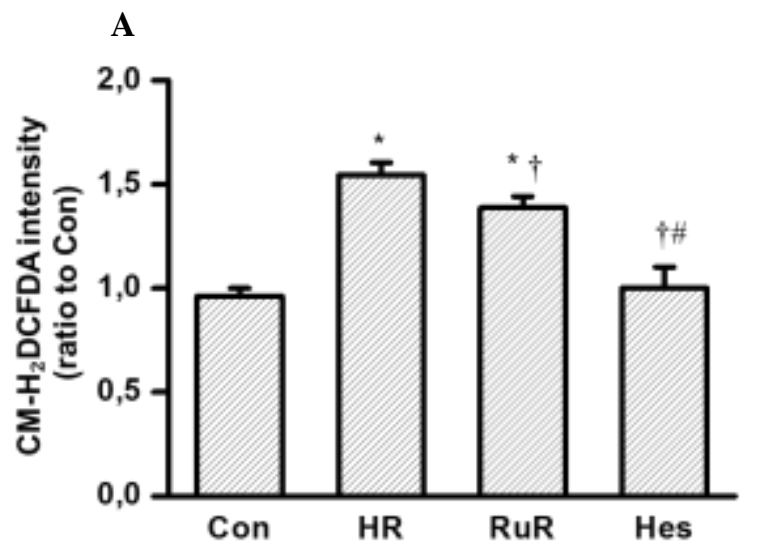

(Figure 2B). The obtained results were consisted with the last study [23], mitochondrial calcium uniporter (MCU) is involved in oxidative stress-induced cell death, representing therapeutic targets for oxidative stress related diseases [23]. Ruthenium red, a well-known MCU inhibitor, delayed the onset of cell death during oxidative stress of rat hepatocytes [24]. Moreover, NecroX-5, a novel MCU inhibitor, protected myocytes and myocardium against HR damage induced by oxidative stress and $\mathrm{Ca}^{2+}$ homeostasis dysregulation [4]. Thus, the present results suggested that Hes exerts antioxidant properties in limiting mitochondrial oxidative stress against HR injury.

B

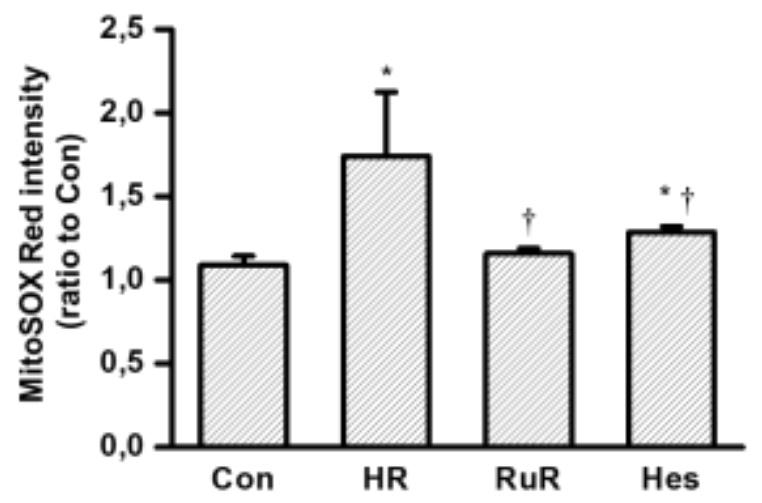

Figure 2. Reactive oxygen species production in H9C2 cells under different conditions.

A: The CM-H $\mathrm{H}_{2}$ DCFDA intensity in different conditioned-H9C2 cells; B: the MitoSOX Red intensity in different conditioned-H9C2 cells. Con: H9C2 cells were cultured in normal condition; HR: H9C2 cells were cultured in HR condition; RuR: H9C2 cells were cultured in conditions of post-hypoxic treatment with

Ruthenium Red; Hes: H9C2 cells were cultured in conditions of post-hypoxic treatment with Hesperidin; * $\mathrm{p}<0.05$ vs. Con, ${ }^{\dagger} \mathrm{p}<0.05$ vs. HR, ${ }^{\#} \mathrm{p}<0.05$ vs. RuR; $\mathrm{n}=3 \div 6$.

\subsection{Hes Ameliorates $\mathrm{Ca}^{2+}$ Homeostasis Dysregulation in H9C2 Cardiomyocytes Against HR Injury}

Dysregulation of $\mathrm{Ca}^{2+}$ homeostasis is one of mitochondrial malfunction indexes. During reoxygenation, mitochondria encounter harsh environmental changes with mitochondrial $\mathrm{Ca}^{2+}$ accumulation and overload [25]. $\mathrm{Ca}^{2+}$ influx from cytosolic to mitochondria during reoxygenation is dependent on the MCU [26]. In this study, the effects of Hes on mitochondrial and cytosolic $\mathrm{Ca}^{2+}$ levels of H9C2 cells under different conditions were evaluated via checking Fluo-4 AM fluorescence intensity and Rhod-2 AM fluorescence intensity. The total intensities of these fluorescence dyes in different cell groups were presented in Figure 3.

The obtained data showed that HR conditions induced the increase in both cytosolic and mitochondrial $\mathrm{Ca}^{2+}$ levels. The increase in $\mathrm{Ca}^{2+}$ was more pronounced in the HR group without any treatment. HR-induced $\mathrm{Ca}^{2+}$ overload was strongly attenuated in the RuR-treated cell group compared with the HR group (Figure 3). Post-hypoxic treatment of Hes 
has no effect on cytosolic $\mathrm{Ca}^{2+}$ in $\mathrm{H} 9 \mathrm{C} 2$ cells (Figure 3A, p>0.05). The Fluo-4 AM fluorescent intensities (ratio to control) in HR and Hes were $1.96 \pm 0.50$ and $1.94 \pm 0.05$, respectively. In contrast to cytosolic $\mathrm{Ca}^{2}$, mitochondrial $\mathrm{Ca} 2+$ level was markedly decreased in Hes-treated cell group. Additionally, RuR group had a lower mitochondrial $\mathrm{Ca}^{2+}$ content compared with the Hes group. Although the influx of $\mathrm{Ca}^{2+}$ into the mitochondria during reoxygenation was strongly inhibited in the RuR group than those

\section{A}

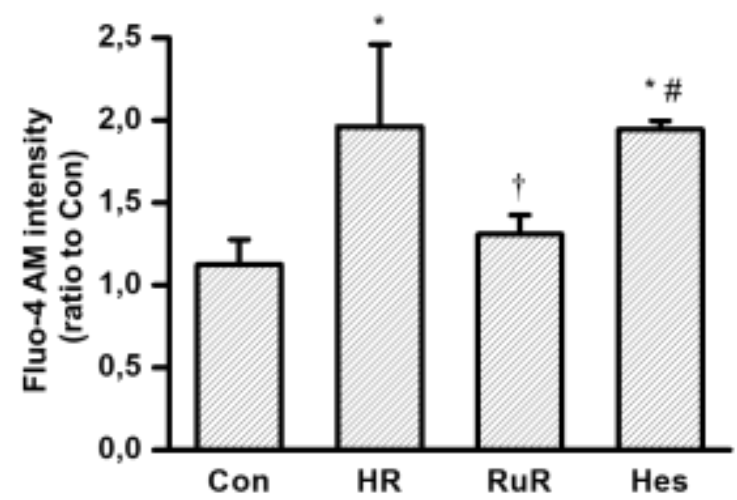

in Hes, the results suggested that Hes may be targeting to MCU. It could be explained by the high level of cytosolic $\mathrm{Ca}^{2+}$ level in Hes-treated group (Figure 3A). Previous study had shown that the high mitochondrial $\mathrm{Ca}^{2+}$ level in the HR group finally led to hypercontracture and cardiac cell death [4].

Similar to RuR (the positive control), Hes post-hypoxic treatment may show its ability to prevent $\mathrm{HR}$-induced $\mathrm{Ca}^{2}$ overload (Figure 3A), subsequently attenuating cardiac cell death as proved in a recent report.

B

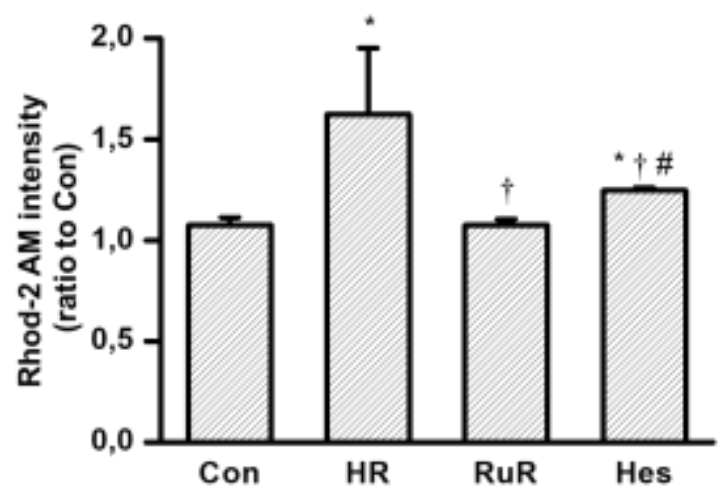

Figure 3. Cytosolic and mitochondrial $\mathrm{Ca}^{2+}$ levels in $\mathrm{H} 9 \mathrm{C} 2$ under different conditions.

A: The Fluo-4 Am intensity in different conditioned-H9C2 cells; B: the Rhod-2 Am intensity in different conditioned-H9C2 cells. Con: H9C2 cells were cultured in normal condition (normoxia); HR: H9C2 cells were cultured in HR condition; RuR: H9C2 cells were cultured in conditions of post-hypoxic treatment with Ruthenium Red; Hes: $\mathrm{H} 9 \mathrm{C} 2$ cells were cultured in conditions of post-hypoxic treatment with Hesperidin; ${ }^{*} \mathrm{p}<0.05$ vs. Con, ${ }^{\dagger} \mathrm{p}<0.05$ vs. HR, ${ }^{\#} \mathrm{p}<0.05$ vs. RuR; $\mathrm{n}=4 \div 6$.

The results show that Hes showed the stronger antioxidant effect on mitochondrial oxidative stress than RuR (Figure 2). In contrast, the effect of Hes on $\mathrm{Ca}^{2+}$ homeostasis regulation was weaker than RuR (Figure 3). Hes has the ability to protect $\mathrm{H} 9 \mathrm{C} 2$ rat cardiomyocytes through targeting mitochondrial oxidative stress and mitochondrial $\mathrm{Ca}^{2+}$ regulation [20]. However, the detail mechanism of Hes on HR-related molecules is still remained and needed to be examined in further study.

\section{Conclusion}

The study demonstrated that post-hypoxic treatment with Hes significantly decreased the mitochondrial oxidative stress and mitochondrial $\mathrm{Ca}^{2+}$ overload in HR-subjected H9C2 cardiomyocytes. Hes may be a promising compound for the attenuation of myocardial damage resulting from HR damage.

\section{Acknowledgements}

We thank Dr. Pham Thi Bich, Ngo Thi Hai Yen, Nguyen Thi Ha Ly, Professor Han Jin for their help and support.

\section{References}

[1] K. A. Reimer, R. B. Jennings, A. H. Tatum, Pathobiology of Acute Myocardial Ischemia: 
Metabolic, Functional and Ultrastructural Studies, Am J. Cardiol, Vol. 52, No. 0002-9149, 1983, pp. 72-81, https://doi.org/10.1016/0002-9149(83)90180-7.

[2] E. Murphy, C. Steenbergen, Mechanisms Underlying Acute Protection from Cardiac Ischemia-reperfusion Injury, Physiol. Rev., Vol. 88, No. 2, 2008, pp. 581-609, https://doi.org/10.1152/physrev.00024.2007.

[3] Vietnam National Heart Association, The $14^{\text {th }}$ Vietnamnational Congress of Cardiology, 2014 of Conference, Da Nang, Available from,

http://daihoi14.vnha.org.vn/, 2014 (accessed on: September 12 $\left.2^{\text {th }}, 2021\right)$.

[4] V. T. Thu, H. K. Kim, L. T. Long, S. R. Lee, T. M. Hanh, T. H. Ko, H. J. Heo, N. Kim, S. H. Kim, K. S. Ko, B. D. Rhee, J. Han, NecroX-5 Prevents Hypoxia/reoxygenation Injury by Inhibiting the Mitochondrial Calcium Uniporter, Cardiovasc Res, Vol. 94, No. 2, 2012, pp. 342-350, https://doi.org/10.1093/cvr/cvs122.

[5] A. K. S. Camara, M. Bienengraeber, D. F. Stowe, Mitochondrial Approaches to Protect Against Cardiac Ischemia and Reperfusion Injury, Front Physiol, Vol. 2, No. 13, 2011, pp. 1-34, https://doi.org/10.3389/fphys.2011.00013.

[6] D. J. Hausenloy, D. M. Yellon, Myocardial Ischemia-reperfusion Injury: A Neglected Therapeutic Target, J. Clin Invest, Vol. 123, No. 1, 2013, pp. 92-100, https://doi.org/10.1172/jci62874.

[7] T. Kalogeris, C. P. Baines, M. Krenz, R. J. Korthuis, Ischemia/Reperfusion, Compr. Physiol., Vol. 7, No. 1, 2016, p. 113-170, https://doi.org/10.1002/cphy.c160006.

[8] A. J. Tompkins, L. S. Burwell, S. B. Digerness, C. Zaragoza, W. L. Holman, P. S. Brookes, Mitochondrial Dysfunction in Cardiac Ischemia-reperfusion Injury: ROS from Complex I, without Inhibition, Biochim Biophys Acta, Vol. 1762, No. 2, 2006, pp. 223-231, https://doi.org/10.1016/j.bbadis.2005.10.001.

[9] Q. Chen, A. K. S. Camara, D. F. Stowe, C. L. Hoppel, E. J. Lesnefsky, Modulation of Electron Transport Protects Cardiac Mitochondria and Decreases Myocardial Injury During Ischemia and Reperfusion, Am J. Physiol Cell Physiol, Vol. 292, No. 1, 2007, pp. 137-147, https://doi.org/10.1152/ajpcell.00270.2006.

[10] T. A. Ajith, T.G. Jayakumar, Mitochondria-targeted Agents: Future Perspectives of Mitochondrial Pharmaceutics in Cardiovascular Diseases, World J. Cardiol, Vol. 6, No. 10, 2014, pp. 1091-1099, https://doi.org/10.4330/wjc.v6.i10.1091.
[11] A. M. Walters, G. A. Porter, P. S. Brookes, Mitochondria as a Drug Target in Ischemic Heart Disease and Cardiomyopathy, Circ Res, Vol. 111, No. 9, 2012, pp. 1222-1236, https://doi.org/10.1161/circresaha.112.265660.

[12] P. T. Thuong, Y. R. Pokharel, M. Y. Lee, S. K. Kim, K. Bae, N. D. Su, W. K. Oh, K. W. Kang, Dual Anti-oxidative Effects of Fraxetin Isolated from Fraxinus rhinchophylla, Biol Pharm Bull, Vol. 32, No. 9, 2009, pp. 1527-32, https://doi.org/10.1248/bpb.32.1527.

[13] N. T. Hoai, L. T. B. Hien, H. V. Duc, L. T. Anh, R. Kaewamatawong, Screening Medicinal Plants in Central Vietnam for Radical Scavenging and Ferrous Ion Chelation Activities, Journal of Medicinal Materials, Vol. 20, No. 3, 2015, pp. 170-175.

[14] T. C. Luan, T. T. T. Quynh, Salihah, Isolation and Identification of Antioxidant Compounds from Leaves of Moringa oleiferam lam, Moringaceae, Ho Chi Minh City Journal of Medicine, Vol. 18, No. 1, 2014, pp. $175-179$.

[15] T. M. Hung, N. H. Dang, N. T. Dat, Methanol Extract from Vietnamese Caesalpinia sappan Induces Apoptosis in HeLa Cells, Biol. Res., Vol. 47, No. 1, 2014, pp. 1-5, https://doi.org/10.1186/0717-6287-47-20.

[16] Y. O. Agrawal, P. K. Sharma, B. Shrivastava, S. Ojha, H. M. Upadhya, D. S. Arya, S. N. Goyal, Hesperidin Produces Cardioprotective Activity Via PPAR- $\gamma$ Pathway in Ischemic Heart Disease Model in Diabetic Rats, PloS one, Vol. 9, No. 11, 2014, pp. e111212-e111212, https://doi.org/10.1371/journal.pone.0111212.

[17] Y. O. Agrawal, P. K. Sharma, B. Shrivastava, D. S. Arya, S. N. Goyal, Hesperidin Blunts Streptozotocin-isoproternol Induced Myocardial Toxicity in Rats by Altering of PPAR- $\gamma$ Receptor, Chem Biol Interact, Vol. 219, 2014, pp. 211-220, https://doi.org/10.1016/j.cbi.2014.06.010.

[18] P. Selvaraj, K. V. Pugalendi, Hesperidin, a Flavanone Glycoside, on Lipid Peroxidation and Antioxidant Status in Experimental Myocardial Ischemic Rats, Redox Rep, Vol. 15, No. 5, 2010, pp. 217-223, https://doi.org/10.1179/135100010x12826446921509.

[19] X. Li, X. Hu, J. Wang, W. Xu, C. Yi, R. Ma, H. Jiang, Short-term Hesperidin Pretreatment Attenuates Rat Myocardial Ischemia/Reperfusion Injury by Inhibiting High Mobility Group Box 1 Protein Expression Via the PI3K/Akt Pathway, Cell. Physiol. Biochem., $\quad$ Vol. No. 5, 2016, pp. 1850-1862, https://doi.org/10.1159/000447884. 
[20] N. T. H. Yen, H. L. Phuong, N. T. H. Ly, P. T. Bich, V. T. Thu, Evaluating the Protective Effects of Hespiridin on H9C2 Cells Against Hypoxia/Reoxygenation Injury in vitro, Proceeding of the $4^{\text {th }}$ National Scientific Conference on Biological Research and Teaching in Vietnam, 2020, pp. 630-637,

https://doi.org/10.15625/vap.2020.00078.

[21] V. T. Thu, N. T. H. Yen, N. T. H. Ly, Liquiritin from Radix Glycyrrhizae Protects Cardiac Mitochondria From Hypoxia/Reoxygenation Damage, J Anal Methods in Chem, Vol. 2021, Articale ID 1857464, 2021, pp. 1-11, https://doi.org/10.1155/2021/1857464.

[22] I. T. Nizamutdinova, J. J. Jeong, G. H. Xu, S. H. Lee, S. S. Kang, Y. S. Kim, K. C. Chang, H. J. Kim, Hesperidin, Hesperidin Methyl Chalone and Phellopterin from Poncirus trifoliata (Rutaceae) Differentially Regulate the Expression of Adhesion Molecules in Tumor Necrosis Factor-alphastimulated Human Umbilical Vein Endothelial Cells, Int Immunopharmacol, Vol. 8, No. 5, 2008, pp. 670-678,

https://doi.org/10.1016/j.intimp.2008.01.011.
[23] Y. Liao, Y. Hao, H. Chen, Q. He, Z. Yuan, J. Cheng, Mitochondrial Calcium Uniporter Protein MCU is Involved in Oxidative Stress-induced Cell Death, Protein and Cell, Vol. 6, No. 6, 2015, pp. 434-442, https://doi.org/10.1007/s13238-015-0144-6.

[24] J. L. Groskreutz, S. F. Bronk, G. J. Gores, Ruthenium Red Delays the Onset of Cell Death During Oxidative Stress of Rat Hepatocytes, Gastroenterology, Vol. 102, No. 3, 1992, pp. 1030-1038, https://doi.org/10.1016/0016-5085(92)90193-3.

[25] M. R. Meana, D. G. Dorado, E. M. Casas, A. Abellán, J. S. Soler, Mitochondrial $\mathrm{Ca}^{2+}$ Uptake During Simulated Ischemia Does Not Affect Permeability Ttransition Pore Opening Upon Simulated Reperfusion, Cardiovas Res, Vol. 71, No. 4, 2006, pp. 715-724, https://doi.org/10.1016/j.cardiores.2006.06.019.

[26] E. J. Griffiths, C. J. Ocampo, J. S. Savage, G. A. Rutter, R. G. Hansford, M. D. Stern, H. S. Silverman, Mitochondrial Calcium Transporting Pathways During Hypoxia and Reoxygenation in Single Rat Cardiomyocytes, Cardiovasc Res, Vol. 39, No. 2, 1998, pp. 423-433, https://doi.org/10.1016/s0008-6363(98)00104-7. 